\title{
Chemical composition of Nigella sativa Linn: Part 2 Recent advances
}

\author{
M. Akram Khan ${ }^{1} \cdot$ M. Afzal ${ }^{2}$
}

Received: 2 February 2016/ Accepted: 15 March 2016/Published online: 11 April 2016

(c) The Author(s) 2016. This article is published with open access at Springerlink.com

\begin{abstract}
The black cumin or Nigella sativa L. seeds have many acclaimed medicinal properties such as bronchodilatory, hypotensive, antibacterial, antifungal, analgesic, anti-inflammatory and immunopotentiating. This review article is an update on the previous article published on Nigella sativa L. in this journal in 1999. It covers the medicinal properties and chemical syntheses of the alkaloids isolated from the seeds of the herb.
\end{abstract}

Keywords Nigella sativa Linn - Chemical composition · Alkaloids · Organic synthesis · Medicinal properties

\section{Introduction}

The chemical composition and biological properties of Nigella sativa L. have previously been reviewed (Khan 1999; Paarakh 2010; Ahmed and El-Mottaleb 2013). In the previous review (Khan 1999) were reported the large variety of organic compounds that are present in the seeds of $N$. sativa $\mathrm{L}$. The seeds of this herb are used in the Middle East and South Asian countries for the treatment of a large variety of ailments and are accepted as a panacea. For

This review article is an update on the previous article published on Nigella sativa Linn in this journal in 1999. It covers the medicinal properties of Nigella sativa and chemical syntheses of the alkaloids isolated from the seeds of the herb.

M. Akram Khan

m.a.khan@shu.ac.uk

1 Biomolecular Science Centre, Sheffield Hallam University, Howard Street, Sheffield S1 1WB, UK

2 Department of Biological Sciences, Faculty of Science, Kuwait University, Kuwait City, Kuwait example, the seeds or oil from the seeds have been used to control diabetes, hypertension, cancer (leukeamia, liver, lung, kidney, prostate, breast, cervix, skin), inflammation, hepatic disorder, arthritis, kidney disorder, cardiovascular complications and dermatological conditions (Khan et al. 2003b, 2011). A GC-MS analysis of the seed extract has shown it to be a mixture of eight fatty acids and 32 volatile terpenes. The major terpenes, thymoquinone (TQ), dithymoquinone (DTQ), trans-anethol, p-cymene, limonine, and carvone have been identified (Nickavar et al. 2003). TQ and DTQ are both cytotoxic for various types of tumors (Worthen et al. 1998). In addition diterpenes, triterpene and terpene alkaloids have been identified in $N$. sativa seeds. The methanolic extract of the seeds contain two types of alkaloids whilst the major principal active ingredient isolated from the volatile oil of $N$. sativa $\mathrm{L}$. is TQ. Since $N$. sativa $\mathrm{L}$. acts as a panacea exhibiting a wide variety of pharmacological actions discussed previously and updated in this report, interest has arisen in the total synthesis of the alkaloids isolated having the isoquinoline and indazole motifs. The isoquinoline alkaloids include nigellicimine (1) and nigellicimine-N-oxide (2), and the indazole alkaloids include nigellidine (3) and nigellicine (4) (Fig. 1). Since the previous review several new dolabellane-type diterpene alkaloids, nigellamines $A_{1}-A_{5}$ (5) have also been isolated from the methanolic extract of the seeds of $N$. sativa $\mathrm{L}$. which have also received synthetic interest (Fig. 1). In this update on $N$. sativa we want to discuss the chemistry of these various alkaloids and TQ under separate headings (Fig. 2).

\section{Pyrazole and indazole ring systems}

Indazole and pyrazole motifs are embedded in numerous pharmaceuticals and agrochemicals with a broad range of 
<smiles>COc1cc2ccnc(C)c2cc1OC</smiles>

(1)

Nigellicimine<smiles>COc1cc2cc[n+]([O-])c(C)c2cc1OC</smiles>

(2)

Nigellicimine $\mathrm{N}$-Oxide<smiles>Cc1cc(O)c2c(-c3ccc([O-])cc3)[n+]3n(c2c1)CCCC3</smiles>

(3)

Nigellidine<smiles>Cc1cc(O)c2c(C(=O)[O-])[n+]3n(c2c1)CCCC3</smiles>

(4)

Nigellicne

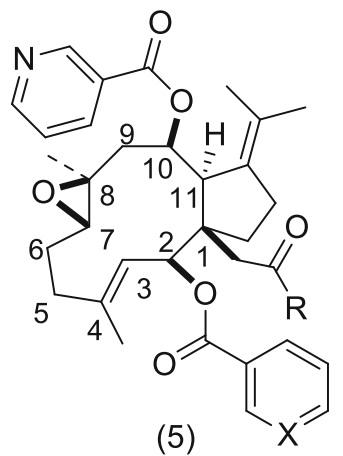

Nigellamines

$A_{1}$ : (5a) $\mathrm{R}=\mathrm{Ph}, \mathrm{X}=\mathrm{CH}$

$A_{2}:(5 b) R=P h, X=N$

$A_{3}:(5 c) R=n-C_{5} H_{11}, X=N$

$A_{4}:(5 d) R=n-C_{3} H_{7}, X=N$

$A_{5}:(5 e) R=\mathrm{PhCH}_{2}, X=\mathrm{N}$

Fig. 1 Structures of alkaloids isolated from Nigella sativa L.<smiles>c1cn[nH]c1</smiles><smiles>c1ccc2n[nH]cc2c1</smiles>

1H-pyrazole<smiles>c1ccc2[nH]ncc2c1</smiles>

$1 \mathrm{H}$-indazole

Fig. 2 Types of indazole ring compounds

biological activities such as (6) (Penning et al. 1997), (7) (Plosker and Goa 1991), (8) (de Paulis et al. 2006), (9) (Okuno et al. 2004), (10) (Maxwell 2000) and (11) (Lahm et al. 2009) shown in Fig. 3.

As a result of these biological activities being associated with the presence of pyrazole and indazole pharmacore in therapeutic compounds, the two indazole alkaloids nigellidine (3) and nigellicine (4) have attracted the attention of synthetic organic chemists for their total syntheses. Thus multigram quantities of these two alkaloids can now be obtained via their total syntheses that should enable their individual therapeutic evaluation to be possible.

\section{Chemistry of the alkaloids and TQ in Nigella sativa}

\section{Total synthesis of nigellidine (3)}

The development of an efficient synthetic method using $\mathrm{Pd}(\mathrm{II}) / \mathrm{Phen}$ catalyst and conditions for the direct $\mathrm{C}-3 \mathrm{C}-\mathrm{H}$ arylation of $(1 \mathrm{H})$ indazole and pyrazole with $\mathrm{ArI}$ or $\mathrm{ArBr}$ was applied to the synthesis of nigellidine as shown in Scheme 1 (Ye et al. 2013). The THP derivative of the commercially available 4-methoxy-6-methyl-(1H)-indazole was reacted with 4-bromoanisole using the C-3 arylation reaction as a key step to form the adduct (14) in $54 \%$ isolated yield on the gram scale. Deprotection of the tetrahydropyranyl (THP) group gave (15) which N-alkylation with 1,4-dibromobutane to afford (16) that underwent intramolecular cyclised to furnish the precursor (17). Demethylation of (17) by treatment with $\mathrm{BBr}_{3}$ afforded the natural product nigellidine (3) as the hydrobromide salt in an overall yield of $18 \%$. 
<smiles>Cc1ccc(-c2cc(C(F)(F)F)nn2-c2ccc(S(N)(=O)=O)cc2)cc1</smiles>

(Anti-inflammatory)<smiles>O=C1c2ccccc2-c2n[nH]c3cccc1c23</smiles>

(9)

Pyrazolanthrone

(Anticancer)<smiles>CN1C2CCC1CC(NC(=O)c1nn(C)c3ccccc13)C2</smiles>

Granisol

(Antiemetic)<smiles>CC(C)OC(=O)c1cc(-c2nn(C)c(C(F)(F)F)c2Br)c(F)cc1Cl</smiles>

Fluazolate

(Herbicide)<smiles>N#Cc1ccc(C(=O)Nc2cc(-c3ccccc3)nn2-c2ccccc2)cc1</smiles>

(Antipsychotic)<smiles>CNC(=O)c1cc(Cl)cc(C)c1NC(=O)c1cc(Br)nn1-c1ncccc1Cl</smiles>

Chlorantraniliprole (Insecticide)

Fig. 3 Structures of some pharmaceuticals and agrochemicals with indazole and pyrazole motifs

\section{The total syntheses of nigellicine (4)}

To date there have been two total syntheses of nigellicine reported. In the first synthesis shown in Scheme 2 commercially available 2-chloro-5-methylphenol (17) was transformed into the protected amide (10) which on lithiation and acylation with diethyloxalate yielded the amide-ester (20) that cyclised on treatment with $6 \mathrm{MHCl}$ acid into the isatin (21) (Elliott et al. 2005). Protection of the keto group in isatin (21) as the dimethyl acetal (22) enabled direct amination at nitrogen to give the hydrazine derivative (22) which on treatment with aqueous acid rearranged into an indazole carboxylic acid that was esterified via an acid chloride into (23). Alkylation of indazole ester (23) with 1,4-dibromobutane and subsequent intramolecular cyclisation produced a 4-methoxy derivative of nigellicine which was deprotected with $\mathrm{PBr}_{3}$ to give nigellicine in an overall yield of $18 \%$.

The second total synthesis of nigellicine (4) shown in Scheme 3 starts with commercially available 2,5dimethylphenol (24) which was converted into 2-bromo-6methoxy-4-methylbenzaldehyde (25) by Clive's method (Inamoto et al. 2007). Treatment of aldehyde (25) with KCN and ethyl chloroformate in the presence of benzyltrimethylammonium chloride (BTAC) and 18-crown-6 in a mixture of water and 1,2-dichloroethane produced an intermediate cyanohydrin carbonate ester which was subsequently converted to a-ketoester (26) by LiHMDS-induced rearrangement. The reaction of (26) with p-toluenesulfonyl hydrazide gave the key intermediate hydrazone (27) as a mixture of $E$ - and $Z$-isomers, which was separable by column chromatography to obtain the major trans isomer that was subsequently converted by Pd-catalysed cyclisation to the indazole (28). Alkylation of the deprotected compound (29) with 1,4-dibromobutane produced the intermediate (30) which underwent intramolecular cyclisation in hot ethanol to furnish the nigellicine ethyl ester hydrobromide salt (31). Finally treatment of ester (31) with $\mathrm{PBr}_{3}$ caused cleavage of the ester group and deprotection of the methoxy group to give nigellicine (4).

\section{Total synthesis of nigellamine $A_{2}(5 b)$}

The delabellane diterpenes are ubiquitous molecules that are produced by animals, plants, fungi and marine sources and have interesting array of biological activities. The alkaloids nigellamines $\mathrm{A}_{1}-\mathrm{A}_{5}$ which have been isolated from $N$. sativa $\mathrm{L}$. belong to the delabellane family of diterpenes and show potent lipid metabolism-promoting activity (Morikawa et al. 2004a). These biologically active alkaloids have complex structural features and have attracted the attention of synthetic organic chemists for their total synthesis.

One enantioselective total synthesis of nigellamine $A_{2}$ has so far been reported (Bian et al. 2006). In this synthesis shown in Scheme 4 the starting lactone-diene (32) was transformed in three steps and on on multigram scale into 
<smiles>COc1cc(C)cc2[nH]ncc12</smiles>

(12)<smiles>COc1cc(C)cc2c1cnn2C1CCCCO1</smiles>

$87 \%$<smiles>COc1ccc(-c2nn(C3CCCCO3)c3c(OC)cc(C)cc23)cc1</smiles>

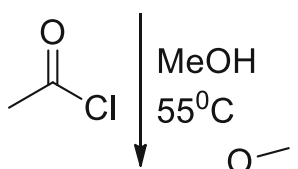

1. $\mathrm{NaH}$

2. $\mathrm{Br}\left(\mathrm{CH}_{2}\right)_{4} \mathrm{Br}$ DMF/DMSO ${ }^{\circ} \mathrm{C}-\mathrm{RT}$<smiles>COc1ccc(-c2n[nH]c3cc(C)cc(OC)c23)cc1</smiles>

$87 \%$
(17) $81 \%$<smiles>COc1ccc(-c2nn(CCCCBr)c3cc(C)cc(OC)c23)cc1</smiles>

(16)

$74 \%$

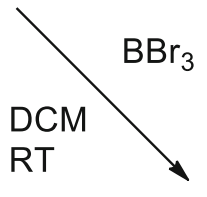<smiles></smiles>

(3)

$74 \%$

Nigellidine hydrobromide

Scheme 1 Total synthesis of nigellidine as the hydrobromide salt

the allylic ester (33) as a key intermediate. Iodolactonisation of diene (33) produced (34) which on radical alkynylation furnished the propynyl lactone (35). Desilylation and reduction of (35) yielded the propynyl lactol (36) which upon in situ iodination and subsequent silylation afforded the vinyl iodide (37) in good yield. The remaining carbon atoms of the nigellamine skeleton were constructed through cross coupling with alkyl zinc reagent and a repeat methylalumination-iodination sequence of reactions to afford substrate (38). Oxidation with pyridinium chlorochromate (PCC) gave an aldehyde at position $\mathrm{C}_{2}$ which upon sonification underwent $\mathrm{Cr}$-mediated cyclisation with the vinyl iodide group at position
$\mathrm{C}_{3}$ to generate the 11-membered compound (39). Reductive opening of the lactone and selective acylation of the primary alcohol gave the substrate (40). Oxidation of (40) with Shi's ketone catalyst and oxone proceeded region- and stereoselectively to produce the desired epoxide-diol as the major product which was acylated with nicotinic acid to furnish ent-nigellamine $A_{2}(5 b)$.

\section{Novel synthetic thymoquinone analogues}

The compound 5-isopropyl-2-methyl-1,4-benzoquinone is known as thymoquinone (TQ) (41) shown in Scheme 5. TQ is the major active principle of the oil of $N$. sativa $\mathrm{L}$. and 


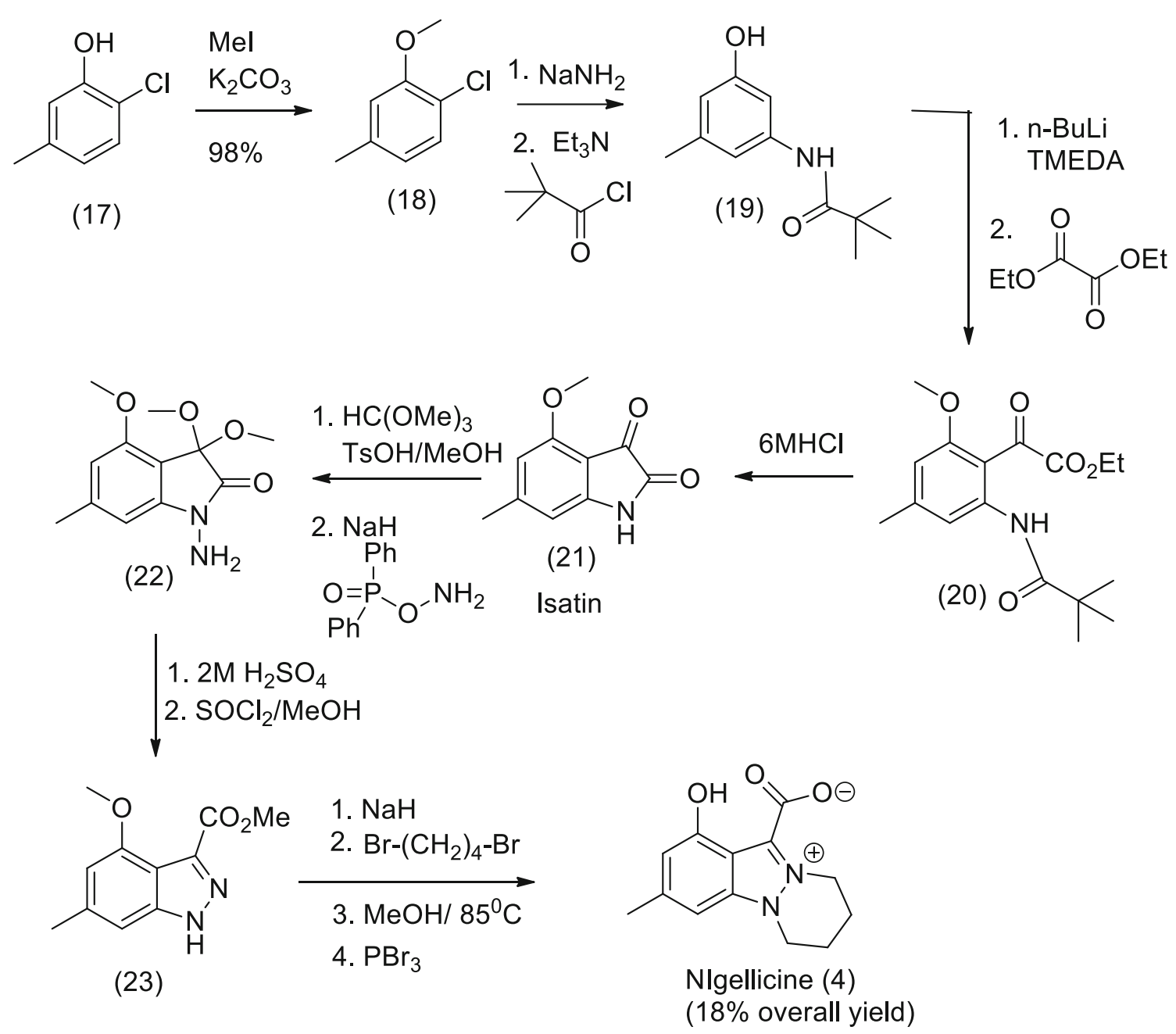

Scheme 2 Total synthesis of nigellicine

has been shown to exhibit anti-tumor activity against breast, lung, prostrate, liver, colon and pancreatic cancer. Thus interest has arisen to synthesise more potent analogues of TQ. Recently reported are the novel analogues of TQ consisting of compounds (44a-b) were synthesised in two steps from TQ Sodium azide added to TQ in acetic acid to afford the reduced product (42) which on reaction with the aldehydes (43a-b) generated the Schiff bases (44a-b) (Yusufi et al. 2013). These analogues have shown superior proliferative activity, excellent chemo-sensitizing activity against pancreatic cancer in vitro and in combination with Gemcitabine.

One serious drawback with TQ is its toxicity at high doses and poor water solubility which limit its usage as a therapeutic agent. In order to alleviate this problem various types of nanocarrier for thymoquinone have been synthesised (Ravindran et al. 2010; Ganea et al. 2010; Alam et al. 2012; Singh et al. 2013). One recent study has reported the synthesis of PAG coated NIPAAM nanoparticles that are encapsulated with TQ for direct hepato-targeting. NIPAAM is a thermosensitive nanopolymer which is widely used as a successful drug delivery system against various diseases and PAG is a galactosylated moiety that targets the liver by interacting with asialoglycoprotein receptor (ASGP-R) present on the surface of hepatocytes and delivers the drug directly to the liver (Verma et al. 2013). The toxicity of the nanocarrier (NIPAAM) at this concentration is almost negligible and due to the size of the nanoparticle being smaller than the already reported nanothymoquinone.

This study clearly has demonstrated that the nanoparticles are able to carry bulk amounts of drug to the liver, and their direct targeting to ASGP-R receptors present on hepatocytes has resulted in significant hepatoprotection at a low dose level that is 1000 times lower than the naked TQ. This nanocarrier approach offers a promising prospect for the future against various liver diseases. 
<smiles>CCOC(=O)C(=O)c1c(Br)cc(C)cc1OC</smiles><smiles>CCOC(=O)c1n[nH]c2cc(C)cc(OC)c12</smiles><smiles>[101In]</smiles><smiles>CCOC(=O)c1nn(CCCCBr)c2cc(C)cc(OC)c12</smiles>

(30)

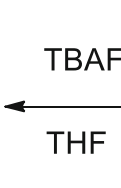

THF<smiles>COc1cc(C)cc2c1c(C(=O)O)nn2[13CH3]</smiles>

(28) ${ }^{\text {Ts }}$

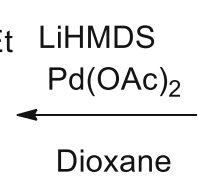

Dioxane<smiles>CCOC(=O)/C(=N/N)c1c(Br)cc(C)cc1OC</smiles>

(27)<smiles>CCOC(=O)/C(=N\N)c1c(Br)cc(C)cc1OC</smiles>

(27)<smiles>CCOC(=O)c1c2n(c3cc(C)cc(OC)c13)N1CCCC[N+]1(Br)[C@H]2C(=O)OCC</smiles>

(31)
(4)

Scheme 3 Second synthesis of nigellicine (4)

\section{Biological activities of Nigella sativa}

\section{The anti-inflammatory activities}

In animal studies $N$. sativa shows dose-dependent suppression of nociceptive pain response and cestocidal activity. These activities are shown by TQ that acts through indirect activation of the supraspinal mu(1)- and kappaopioid receptor subtypes (Abdel-Fattah et al. 2000; Akhtar and Riffat 1991). The antihypertensive principal TQ and other constituents of $N$. sativa are also protective agents against the chromosomal aberrations induced by schistosomiasis (Aboul-El-Ela 2002; El Tahir et al. 1993a). These compounds are used in the control of arterial blood pressure, anticholinergic, antihistaminic, tracheal relaxation, control of asthma and in the treatment of other allergic diseases (Ahmed and El-Mottaleb 2013; Al-Majed et al. 2001; Boskabady et al. 2004; Kalus et al. 2003; Steinmann et al. 1997) (Fig. 4).

Nigellone (dithymoquinone) is the carbonyl dimer of TQ present in N. sativa and it inhibits the release of histamine giving relief in asthmatic conditions (Chakravarty 1993; El Tahir et al. 1993b). The spasmolytic and bronchodilator activities of $N$. sativa are mediated possibly through calcium channel blockade (Gilani et al. 2001). Physologically important activities shown by $N$. sativa include analgesic, anti-inflammatory, antimicrobial, antifungal and antibacterial effects (Hanafy and Hatem 1991; Khan et al. 2003a; Morsi 2000) and CNS activity of its aqueous extract and volatile oil components (Al-Ghamdi 2001; Al-Naggar et al. 2003; Hajhashemi et al. 2004; Haq et al. 1995). The neuroprotective activity of $N$. sativa on neurotransmitter leading to antiepileptic activity has also been described (Arafa et al. 2013). TQ, through an opioid receptor-mediated, increases in GABAergic tone, exhibits anticonvulsant activity in the petit mal epilepsy (Hosseinzadeh and Parvardeh 2004).

\section{Antiulcer and anticancer properties}

Ethanol induced ulcer in rats has been reduced by $N$. sativa extracts (El-Dakhakhny et al. 2000a, b). Ischaemia/reperfusion are linked by free radical generation and this could be controlled by an administration of TQ which could offer gastroprotective effects against gastric lesions (El-Abhar et al. 2003). The chemosensitising effect of TQ in the treatment of 5-Fluorouracil induced gastric cancer has been reported (Lei et al. 2012). 
<smiles>C=CC=C1CCOC1=O</smiles>

(32)<smiles>C=CC1C(=C(C)C)CCC1(OCC)C(=O)OCC</smiles>

(34)

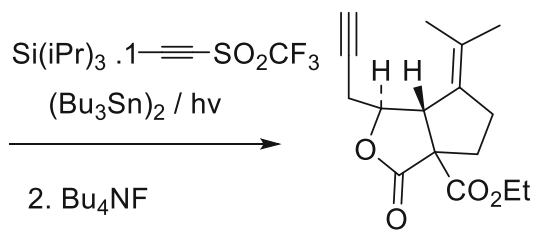

(35)

$$
\begin{aligned}
& \text { 1. }(\mathrm{Bu})_{2} \mathrm{AlH} \\
& \text { 2. } \mathrm{NaBH}_{4}
\end{aligned}
$$

1. $\mathrm{PdCl}_{2}(\mathrm{dpf})$<smiles>CC(C)=CCC=C(C)C[C@@H]1O[C@H](O)[C@]2(CO)CCC(=C(C)C)[C@H]2[C@H]1C</smiles>

(38)

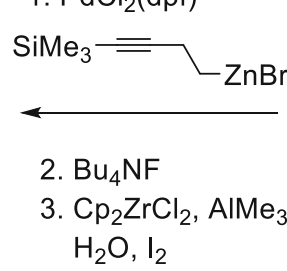<smiles>CC(C)=C1CCC23O[Ge](C)(C)CC2OC2OC(C/C(C)=C/I)C123</smiles>

(37)<smiles>C#CC[C@H]1OC(O)C2(CO)CCC(=C(C)C)[C@H]1[C@H]2O[C@H](C)C(=O)OCC</smiles>

(36)

1. PCC

2. $\mathrm{CrCl}_{2} / \mathrm{Ni}(\mathrm{acac})_{2}$ sonification

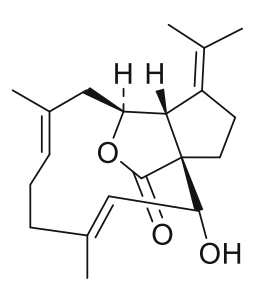

(39)

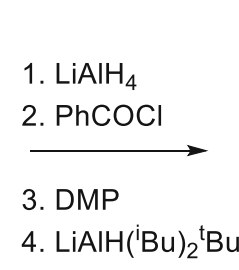

3. DMP 4. $\mathrm{LiAlH}(\mathrm{Bu})_{2}{ }^{\mathrm{t}} \mathrm{Bu}$

(40)

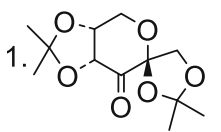

(Shi's catalyst) Oxone

2. Nicotinic acid DCC, DMAP

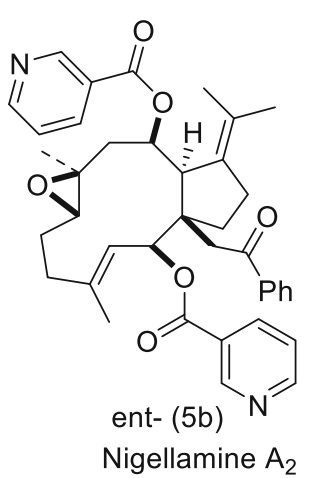

Scheme 4 Total synthesis of nigellamine $A_{2}$

\section{Hepato-protective antioxidant activities}

The aqueous extract of $N$. sativa (NS) is hepato-protective against carbon tetrachloride induced oxidative hepatic damage suggesting powerful antioxidative properties of NS extract (Al-Ghamdi 2003; El-Dakhakhny et al. 2000a, b; Mansour et al. 2001; Meral and Kanter 2003). NS protects liver by inhibiting enzyme leakage from hepatocytes caused by toxic substances such as carbon tetrachloride (Kanter et al. 2003a). Through its antioxidant action, TQ is known to inhibit 5-lipoxigenase and 5-hydroxy-eicosatetraenoic acid (5-HETE) products suggesting its use in inflammatory pathogenesis (El-Dakhakhny et al. 2002a). Hyperhomocysteinemia (HHcy) has been linked with oxidative stress. Therefore, NS has been demonstrated to improve total antioxidant status in rats treated with methionine induced HHcy (El-Saleh et al. 2004). The oxygen free radical generated by gentamicin pathogenesis causing hepatotoxicity and nephrotoxicity are quenched by oil and seeds of NS (Ali 2004) and the ethanolic extracts of NS have the potential to protect against gama-radiation induced oxidative damage (Rastogi et al. 2010). It has been reported that TQ inhibits the leakage of hepatic enzymes and the intracellular depletion of GSH protecting liver (Daba and Abdel-Rahman 1998).

\section{Immunomodulatory effect}

NS has established immunosuppressive and cytotoxic properties (Islam et al. 2004) and the pharmacological and therapeutical properties of NS have been reviewed by many workers (Ahmad et al. 2013; Ali and Blunden 2003; Swamy and Tan 2000). The splenocyte proliferation, macrophage function, and NK anti-tumor activity of NS have revealed the potent immunomodulatory properties of the Nigella seeds (Majdalawieh et al. 2010). The NS seed 
<smiles>CC1=CC(=O)C(C(C)C)=CC1=O</smiles>

(41)<smiles>CC1=C(N)C(=O)C(C(C)C)=CC1=O</smiles>

(42)<smiles>[R3]c1ccc(C=O)c([R])c1[R]</smiles>

(43)

$$
\begin{gathered}
\text { a. } R_{1}=R_{2}=R_{3}=O H \\
\text { b. } R_{1}=R_{2}=R_{3}=F
\end{gathered}
$$

Scheme 5 Synthesis of thymoquinone alanogues as anticancer agents

Fig. 4 Chemical structures of principal active ingredient isolated from the volatile oil of Nigella sativa $\mathrm{L}$.<smiles>Cc1ccc(C(C)C)c(O)c1</smiles>

Thymole<smiles>CC1=CC(=O)C(C(C)C)=CC1=O</smiles>

Thymoquinone<smiles>CC(C)C1=CC(=O)C2(C)C(C1=O)C1C(=O)C=C(C(C)C)C(=O)C12C</smiles>

Dithymoquinone (Nigellone) oil also shows hepatoprotective action against hypervitaminosis A and humoral immune responses and non-specific cellular immune responses (Al-Suhaimi 2012; Al-shatwi 2014). The immune modulating effect of NS is mediated through direct stimulation of macrophage phagocytic activity or lymphocytes activation (Fararh et al. 2004; Haq et al. 1999).

NS is a known immune stimulant that protects against many pathological conditions (Corder et al. 2003; Fararh et al. 2004). Thus, the powerful antioxidative and protective properties of TQ in proteinuria and hyperlipidemia associated with nephrotic syndrome have been evaluated (Badary et al. 2000). Along with TQ and other terpenoid compounds such as carvacrol, trans-anethole and 4-terpineol with antioxidant properties have been reported for NS (Burits and Bucar 2000). Carvacrol is a known inhibitor of human neutrophil elastase and may be useful agent in phytotherapy for injuries such as chronic obstructive pulmonary disease and emphysema (Kacem and Meraihi 2006). The volatile NS oil shows anti-oxytocic and sperm characteristics due to its antioxidant activities (Mansour et al. 2013; Aqel and Shaheen 1996).

\section{Effect on blood sugar and lipid profile}

Streptozotocin (STZ) treated animals respond to NS extracts with normalizing blood glucose through extrapancreatic actions rather than by stimulated insulin release and ascertain to be protective against type-2 diabetes (ElDakhakhny et al. 2002b; Fararh et al. 2002, 2004; Hawsawi et al. 2001). The significant increase in lipid peroxidation by STZ is also controlled by NS and has protective effect in diabetes by decreasing oxidative stress and regeneration/ proliferation of the beta-cells in the islets of Langerhans (Kanter et al. 2003b, 2004). A petroleum ether extract of NS exhibits insulin-sensitizing activity (Le et al. 2004) and the mechanism of NS extract in the control of diabetes has ben shown to be through controlled insulin release (Rchid et al. 2004). At the same time, amendment in the blood lipids profile has been suggested by the use of NS extracts 
(El-Dakhakhny et al. 2000a, b). Arachidonic acid induced blood platelet aggregation and blood coagulation are inhibited by NS indicating its potential use in thrombosis (Enomoto et al. 2001). TQ is involved in the inhibition of arachidonic acid generated eicosanoids and lipid peroxidation (Houghton et al. 1995).

\section{Effect on arthritis}

In human, TQ has been shown to be effective in rheumatoid arthritis (Gheita and Kenawy 2012). Inhibition of arachidonic acid generated eicosanoids (thromboxane B2, leukotriene B4) supports the use of NS for the treatment of rheumatoid arthritis and other inflammatory diseases (Houghton et al. 1995). TQ has been implicated in bone healing in an animal model (Kirui et al. 2004). Inhibition of leukotrienes through 5-lipoxygenase and LTC4 synthase activities in eicosanoid pathway has been well documented (Mansour and Tornhamre 2004).

\section{Anticancer activity of TQ}

A number of antitumor compounds have been identified from NS. These compounds are TQ, alpha-hederin a triterpene, isopropylmethylphenols and dollabelane-type diterpene alkaloid nigellamine A3, A4, A5 and C (Kumara and Huat 2001; Michelitsch et al. 2004; Morikawa et al. 2004a, b). Thus, numerous types of cancers such as Ehrlich ascites carcinoma (EAC), Dalton's lymphonia ascites (DLA) and Sarcoma-180 (S-180) cells, colon carcinoma, pancreatic carcinoma and hepatic carcinoma have been treated with NS extracts in vitro (Salomi et al. 1992; Samarakoon et al. 2010). Changes in intracellular GSH and redox status for mitochondrial function are important factors in the mechanism of alpha-hederin induced cell death (Swamy and Huat 2003) (Fig. 5).

The NS extract exerts anti-hepatocarcinoma effect through modulation of apoptosis (Samarakoon et al. 2012). The regulation of pro- and anti apoptic genes by NS has been demonstrated in treating cervical cancer (Shafi et al. 2009). In many cases the antitumor activity of NS seeds has been attributed to the volatile component thymoquinone (structurally related to tert-butylhydroquinone, a potent antioxidant) that has the potential to protect rat liver against diethynitrosamine (DEN) induced hepatocarcinogenesis (Iddamaldeniya et al. 2003). It also improves the therapeutic efficacy of ifosfamide by decreasing nephrotoxicity and improving antitumor activity (Badary 1999; Saleem et al. 2012).

TQ also affects the benzo-a-pyrene induced clastogenic activity in rats and 20-methylcycloanthrene induced fibrocarcinoma is inhibited by TQ present in NS extracts (Badary et al. 2007; Badary and Gamal El-Din 2001).

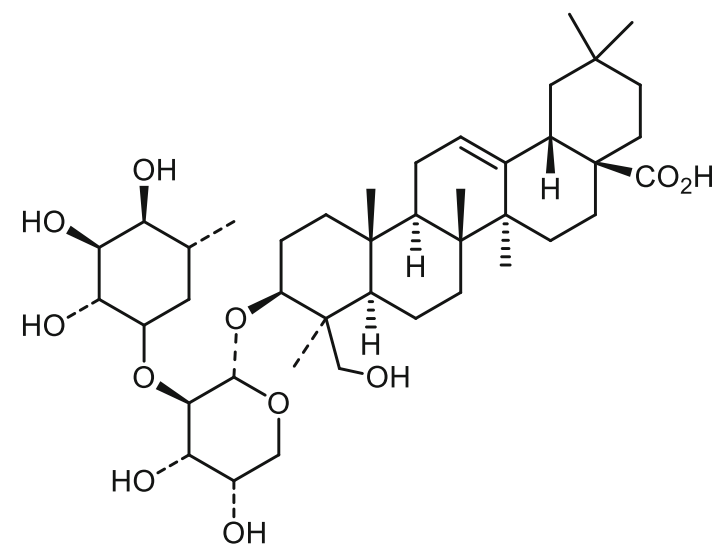

Fig. 5 Chemical structure of $\alpha$-hederin

While supplementation by NS and honey in the treatment of methylnitrosourea induced inflammation, carcinogenesis and oxidative stress has been reported (Mabrouk et al. 2002), the lipid peroxidation induced liver damage in diabetic rats has also been mentioned (Meral et al. 2001).

The pro-oxidant nitric oxide production is inhibited by NS extracts validating the fact that NS has anti-inflammatory activities (Mahmood et al. 2003). Model in vivo experiments with Schistosomiasis mansoni infected mice have concluded that NS extract have a great protective potential against oxidative stress protecting liver (Mahmoud et al. 2002). The mode of action of TQ against cancer has been suggested to be through its antioxidative properties and interaction with DNA synthesis. The antioxidant and pro-oxidant properties of TQ have been substantiated by augmented TQ mediated scavenging of superoxide anion (Badary et al. 2003). However, presence of the phenolic compounds in NS, such as vanillic acid, could also contribute to the antioxidant properties of NS. These compounds may also be responsible for its antimutagenic activities (Bourgou et al. 2008; Khader et al. 2010). TQ exhibits advanced antimyeloma activity in MDN and XD2 multiple myeloma malignant plasma cells (Badr et al. 2011). However, the mechanism of chemotaxis of malignant plasma cells is not well defined.

\section{Effect of TQ on pancreatic carcinoma (PC)}

$\mathrm{PC}$ is one of the most deadly cancers with almost invariably fatal consequences. TQ has antitumor activity against PC. To combat PC, the dose of TQ has to be high. Therefore, many attempts have been made to study structure activity relationships by synthesizing TQ analogs and some of these compounds have potent antitumor activity against PC (Banerjee et al. 2010). Gemcitabine- or oxaliplatin-induced activation of NF-kappaB is inhibited by TQ, 
resulting in the chemosensitization of pancreatic tumors to conventional therapeutics (Banerjee et al. 2009). Progressive apoptosis is also inhibited by NS (Corder et al. 2003).

\section{Co-administration of NS with other substances}

Cisplatin is a widely used drug that induces kidney toxicity. It has been established that when cisplatin is coadministered with NS, the nephrotoxicity is reduced (ElDaly 1998; Nair et al. 1991; Ulu et al. 2012). A co-administration of NS with green tea extract prevents cytotoxicity of organophosphorus compounds (Korany and Ezzat 2011). Co-administration of saffron with NS in the treatment of chemical carcinogenesis has also been reported (Salomi et al. 1991).

\section{Breast cancer}

It is one of the most common causes of death in women and there is no effective treatment except mastectomy. Many substances have been shown to have mammary anticancer activity and among these are melotonin and retinoic acid. NS has been examined in animals exposed to 7,12-dimethylbenz(a)anthracene (DMBA), mammary cancer causing substance which showed NS reduces the carcinogenic effects of DMBA (El-Aziz et al. 2005). Inactivation of MCF-7 breast cancer cells has been demonstrated by NS extracts (Farah and Begum 2003).

\section{Colon cancer}

The molecular mechanism of action of TQ in colon cancer has been suggested. Thus, colon cancer is inhibited in G1 phase cell cycle and apoptosis is mediated by TQ (GaliMuhtasib et al. 2004). The 1,2-dimethylhydrazine (DMH), colon cancer inducer, damage erythrocytes has been reported and NS has the ability to detoxify DMH (Harzallah et al. 2012; Worthen et al. 1998). The preneoplastic lesions for colon cancer have been investigated and found that colon cancer in post-initiation stage can be prevented by volatile components of Nigella seeds (Salim and Fukushima 2003).

\section{Conclusion}

The Islamic claim made by prophet Muhammad over 1400 years ago that "black seed ( N. sativa Linn) has the cure for all deseases" has a much more meaningful and acceptable dimension to it given the overwhelming scientific data obtained, as outlined in the reviews, that supports it. The alkaloids present in $N$. sativa Linn could now be obtained by total synthesis and the study of their pharmacological properties should make very interesting research studies for the future.

Acknowledgments We thank Professor K.D. Rainsford for his encouragement and helpful suggestions in writing this second review.

Open Access This article is distributed under the terms of the Creative Commons Attribution 4.0 International License (http:// creativecommons.org/licenses/by/4.0/), which permits unrestricted use, distribution, and reproduction in any medium, provided you give appropriate credit to the original author(s) and the source, provide a link to the Creative Commons license, and indicate if changes were made.

\section{References}

Abdel-Fattah AM, Matsumoto K, Watanabe H (2000) Antinociceptive effects of Nigella sativa oil and its major component, thymoquinone, in mice. Eur J Pharmacol 400(1):89-97

Aboul-El-Ela EI (2002) Cytogenetic studies on Nigella sativa seeds extract and thymoquinone on mouse cells infected with schistosomiasis using karyotyping. Mut Res 516(1-2):11-17

Ahmad A, Husain A, Mujeeb M, Khan SA, Najmi AK, Siddique NA, Damanhouri ZA, Anwar F (2013) A review on therapeutic potential of Nigella sativa: a miracle herb. Asian Pac J Trop Biomed 3(5):337-352

Ahmed OG, El-Mottaleb NA (2013) Renal function and arterial blood pressure alterations after exposure to acetaminophen with a potential role of Nigella sativa oil in adult male rats. J Physiol Biochem 69(1):1-13

Akhtar MS, Riffat S (1991) Field trial of Saussurea lappa roots against nematodes and Nigella sativa seeds against cestodes in children. JPMA J Pak Med Assoc 41(8):185-187

Alam S, Khan ZI, Mustafa G, Kumar M, Islam F, Bhatnagar A, Ahmad FJ (2012) Development and evaluation of thymoquinone-encapsulated chitosan nanoparticles for nose-to-brain targeting: a pharmacoscintigraphic study. Int $\mathrm{J}$ Nanomed 7:5705-5718

Al-Ghamdi MS (2001) The anti-inflammatory, analgesic and antipyretic activity of Nigella sativa. J Ethnopharm 76(1):45-48

Al-Ghamdi MS (2003) Protective effect of Nigella sativa seeds against carbon tetrachloride-induced liver damage. Am J Chin Med 31(5):721-728

Ali BH (2004) The effect of Nigella sativa oil on gentamicin nephrotoxicity in rats. Am J Chin Med 32(1):49-55

Ali BH, Blunden G (2003) Pharmacological and toxicological properties of Nigella sativa. Phytother Res 17(4):299-305

Al-Majed AA, Daba MH, Asiri YA, Al-Shabanah OA, Mostafa AA, El-Kashef HA (2001) Thymoquinone-induced relaxation of guinea-pig isolated trachea. Res Commun Mol Pathol Pharmacol 110(5-6):333-345

Al-Naggar TB, Gomez-Serranillos MP, Carretero ME, Villar AM (2003) Neuropharmacological activity of Nigella sativa L. extracts. J Ethnopharm 88(1):63-68

Al-shatwi AA (2014) Bioactivity-guided identification to delineate the immunomodulatory effects of methanolic extract of Nigella sativa seed on human peripheral blood mononuclear cells. Chin J Integr Med. doi:10.1007/s11655-013-1534-3

Al-Suhaimi EA (2012) Hepatoprotective and immunological functions of Nigella sativa seed oil against hypervitaminosis A in adult male rats. Int J Vitam Nutr Res 82(4):288-297 
Aqel M, Shaheen R (1996) Effects of the volatile oil of Nigella sativa seeds on the uterine smooth muscle of rat and guinea pig. J Ethnopharmacol 52(1):23-26

Arafa NM, Abdel-Rahman M, El-khadragy MF, Kassab RB (2013) Evaluation of the possible epileptogenic activity of ciprofloxacin: the role of Nigella sativa on amino acids neurotransmitters. Neurochem Res 38(1):174-185

Badary OA (1999) Thymoquinone attenuates ifosfamide-induced Fanconi syndrome in rats and enhances its antitumor activity in mice. J Ethnopharmacol 67(2):135-142

Badary OA, Gamal El-Din AM (2001) Inhibitory effects of thymoquinone against 20-methylcholanthrene-induced fibrosarcoma tumorigenesis. Cancer Detect Prev 25(4):362-368

Badary OA, Abdel-Naim AB, Abdel-Wahab MH, Hamada FM (2000) The influence of thymoquinone on doxorubicin-induced hyperlipidemic nephropathy in rats. Toxicology 143(3):219-226

Badary OA, Taha RA, Gamal el-Din AM, Abdel-Wahab MH (2003) Thymoquinone is a potent superoxide anion scavenger. Drug Chem Toxicol 26(2):87-98

Badary OA, Abd-Ellah MF, El-Mahdy MA, Salama SA, Hamada FM (2007) Anticlastogenic activity of thymoquinone against benzo(a)pyrene in mice. Food Chem Toxicol 45(1):88-92

Badr G, Lefevre EA, Mohany M (2011) Thymoquinone inhibits the CXCL12-induced chemotaxis of multiple myeloma cells and increases their susceptibility to Fas-mediated apoptosis. PLoS One 6(9):e23741

Banerjee S, Kaseb AO, Wang Z, Kong D, Mohammad M, Padhye S et al (2009) Antitumor activity of gemcitabine and oxaliplatin is augmented by thymoquinone in pancreatic cancer. Cancer Res 69(13):5575-5583

Banerjee S, Azmi AS, Padhye S, Singh MW, Baruah JB, Philip PA et al (2010) Structure-activity studies on therapeutic potential of Thymoquinone analogs in pancreatic cancer. Pharm Res 27(6):1146-1158

Bian J, Van Wingerden M, Ready JM (2006) Enantioselective total synthesis of (+)- and (-)-nigellamine A2. J Am Chem Soc 128:7428-7429

Boskabady MH, Shirmohammadi B, Jandaghi P, Kiani S (2004) Possible mechanism(s) for relaxant effect of aqueous and macerated extracts from Nigella sativa on tracheal chains of guinea pig. BMC Pharmacol 4:3

Bourgou S, Ksouri R, Bellila A, Skandrani I, Falleh H, Marzouk B (2008) Phenolic composition and biological activities of Tunisian Nigella sativa L. shoots and roots. C R Biol 331(1):48-55

Burits M, Bucar F (2000) Antioxidant activity of Nigella sativa essential oil. Phytother Res 14(5):323-328

Chakravarty N (1993) Inhibition of histamine release from mast cells by nigellone. Ann Allergy Asthma Immunol 70(3):237-242

Corder C, Benghuzzi H, Tucci M, Cason Z (2003) Delayed apoptosis upon the treatment of Hep-2 cells with black seed. Biomed Sci Instrum 39:365-370

Daba MH, Abdel-Rahman MS (1998) Hepatoprotective activity of thymoquinone in isolated rat hepatocytes. Toxicol Lett 95(1):23-29

de Paulis T, Hemstapat K, Chen Y, Zhang Y, Saleh S, Alagille D et al (2006) Substituent effects of N-(1,3-Diphenyl-1H-pyrazol-5yl)benzamides on positive allosteric modulation of the metabotropic glutamate-5 receptor in rat cortical astrocytes. J Med Chem 49:3332-3344

El Tahir KE, Ashour MM, Al-Harbi MM (1993a) The cardiovascular actions of the volatile oil of the black seed (Nigella sativa) in rats: elucidation of the mechanism of action. Gen Pharmacol 24(5):1123-1131

El Tahir KE, Ashour MM, Al-Harbi MM (1993b) The respiratory effects of the volatile oil of the black seed (Nigella sativa) in guinea-pigs: elucidation of the mechanism(s) of action. Gen Pharmacol 24(5):1115-1122

El-Abhar HS, Abdallah DM, Saleh S (2003) Gastroprotective activity of Nigella sativa oil and its constituent, thymoquinone, against gastric mucosal injury induced by ischaemia/reperfusion in rats. J Ethnopharmacol 84(2-3):251-258

El-Aziz MA, Hassan HA, Mohamed MH, Meki AR, Abdel-Ghaffar SK, Hussein MR (2005) The biochemical and morphological alterations following administration of melatonin, retinoic acid and Nigella sativa in mammary carcinoma: an animal model. Int J Exp Pathol 86(6):383-396

El-Dakhakhny M, Mady NI, Halim MA (2000a) Nigella sativa L. oil protects against induced hepatotoxicity and improves serum lipid profile in rats. Arzneimittel-Forschung 50(9):832-836

El-Dakhakhny M, Barakat M, Halim MA, Aly SM (2000b) Effects of Nigella sativa oil on gastric secretion and ethanol induced ulcer in rats. J Ethnopharmacol 72(1-2):299-304

El-Dakhakhny M, Madi NJ, Lembert N, Ammon HP (2002a) Nigella sativa oil, nigellone and derived thymoquinone inhibit synthesis of 5-lipoxygenase products in polymorphonuclear leukocytes from rats. J Ethnopharmacol 81(2):161-164

El-Dakhakhny M, Mady N, Lembert N, Ammon HP (2002b) The hypoglycemic effect of Nigella sativa oil is mediated by extrapancreatic actions. Planta Med 68(5):465-466

El-Daly ES (1998) Protective effect of cysteine and vitamin E, Crocus sativus and Nigella sativa extracts on cisplatin-induced toxicity in rats. J Pharm Belg 53(2):87-93

Elliott EL, Bushell SM, Cavero M, Tolan B, Kelly TR (2005) Total synthesis of nigellicine and nigeglanine hydrobromide. Org Lett 7(12):2449-2451

El-Saleh SC, Al-Sagair OA, Al-Khalaf MI (2004) Thymoquinone and Nigella sativa oil protection against methionine-induced hyperhomocysteinemia in rats. Inter J Cardiol 93(1):19-23

Enomoto S, Asano R, Iwahori Y, Narui T, Okada Y, Singab AN et al (2001) Hematological studies on black cumin oil from the seeds of Nigella sativa L. Biol Pharm Bull 24(3):307-310

Farah IO, Begum RA (2003) Effect of Nigella sativa (N. sativa L.) and oxidative stress on the survival pattern of MCF-7 breast cancer cells. Biomed Sci Instrum 39:359-364

Fararh KM, Atoji Y, Shimizu Y, Takewaki T (2002) Isulinotropic properties of Nigella sativa oil in Streptozotocin plus Nicotinamide diabetic hamster. Res Vet Sci 73(3):279-282

Fararh KM, Atoji Y, Shimizu Y, Shiina T, Nikami H, Takewaki T (2004) Mechanisms of the hypoglycaemic and immunopotentiating effects of Nigella sativa L. oil in streptozotocin-induced diabetic hamsters. Res Vet Sci 77(2):123-129

Gali-Muhtasib H, Diab-Assaf M, Boltze C, Al-Hmaira J, Hartig R, Roessner A et al (2004) Thymoquinone extracted from black seed triggers apoptotic cell death in human colorectal cancer cells via a p53-dependent mechanism. Int J Oncol 25(4): $857-866$

Ganea GM, Fakayode SO, Losso JN, van nostrum CF, Sabliov CM, Warner IM (2010) Delivery of phytochemical thymoquinone using molecular micelle modified poly(D, L lactide-co-glycolide) (PLGA) nanoparticles. Nanotechnology 21(28):285104

Gheita TA, Kenawy SA (2012) Effectiveness of Nigella sativa oil in the management of rheumatoid arthritis patients: a placebo controlled study. Phytother Res 26(8):1246-1248

Gilani AH, Aziz N, Khurram IM, Chaudhary KS, Iqbal A (2001) Bronchodilator, spasmolytic and calcium antagonist activities of Nigella sativa seeds (Kalonji): a traditional herbal product with multiple medicinal uses. J Pak Med Assoc 51(3):115-120

Hajhashemi V, Ghannadi A, Jafarabadi H (2004) Black cumin seed essential oil, as a potent analgesic and antiinflammatory drug. Phytother Res 18(3):195-199 
Hanafy MS, Hatem ME (1991) Studies on the antimicrobial activity of Nigella sativa seed (black cumin). J Ethnopharmacol 34(2-3):275-278

Haq A, Abdullatif M, Lobo PI, Khabar KS, Sheth KV, Al-Sedairy ST (1995) Nigella sativa: effect on human lymphocytes and polymorphonuclear leukocyte phagocytic activity. Immunopharmacology 30(2):147-155

Haq A, Lobo PI, Al-Tufail M, Rama NR, Al-Sedairy ST (1999) Immunomodulatory effect of Nigella sativa proteins fractionated by ion exchange chromatography. Int $\mathrm{J}$ Immunopharmacol 21(4):283-295

Harzallah HJ, Grayaa R, Kharoubi W, Maaloul A, Hammami M, Mahjoub T (2012) Thymoquinone, the Nigella sativa bioactive compound, prevents circulatory oxidative stress caused by $1,2-$ dimethylhydrazine in erythrocyte during colon postinitiation carcinogenesis. Oxid Med Cell Longev 2012:854065

Hawsawi ZA, Ali BA, Bamosa AO (2001) Effect of Nigella sativa (black seed) and thymoquinone on blood glucose in albino rats. Ann Saudi Med 21(3-4):242-244

Hosseinzadeh H, Parvardeh S (2004) Anticonvulsant effects of thymoquinone, the major constituent of Nigella sativa seeds, in mice. Phytomedicine 11(1):56-64

Houghton PJ, Zarka R, de las Heras B, Hoult JR (1995) Fixed oil of Nigella sativa and derived thymoquinone inhibit eicosanoid generation in leukocytes and membrane lipid peroxidation. Planta Med 61(1):33-36

Iddamaldeniya SS, Wickramasinghe N, Thabrew I, Ratnatunge N, Thammitiyagodage MG (2003) Protection against diethylnitrosoamine-induced hepatocarcinogenesis by an indigenous medicine comprised of Nigella sativa, Hemidesmus indicus and Smilax glabra: a preliminary study. J Carcinogen 2(1):6

Inamoto K, Katsuno M, Yoshino T, Arai Y, Hiroyaa K, Sakamotoa T (2007) Synthesis of 3-substituted indazoles and benzoisoxazoles via Pd-catalyzed cyclization reactions: application to the synthesis of nigellicine. Tetrahedron 63:2695-2711

Islam SN, Begum P, Ahsan T, Huque S, Ahsan M (2004) Immunosuppressive and cytotoxic properties of Nigella sativa. Phytother Res 18(5):395-398

Kacem R, Meraihi Z (2006) Effects of essential oil extracted from Nigella sativa (L) seeds and its main components on human neutrophil elastase activity. Yakugaku Zasshi J Pharm Soc Jpn 126(4):301-305

Kalus U, Pruss A, Bystron J, Jurecka M, Smekalova A, Lichius JJ et al (2003) Effect of Nigella sativa (black seed) on subjective feeling in patients with allergic diseases. Phytother Res 17(10):1209-1214

Kanter M, Meral I, Dede S, Gunduz H, Cemek M, Ozbek H et al (2003a) Effects of Nigella sativa L. and Urtica dioica L. on lipid peroxidation, antioxidant enzyme systems and some liver enzymes in CCl4-treated rats. J Vet Med A Physiol Pathol Clin Med 50(5):264-268

Kanter M, Meral I, Yener Z, Ozbek H, Demir H (2003b) Partial regeneration/proliferation of the beta-cells in the islets of Langerhans by Nigella sativa L. in streptozotocin-induced diabetic rats. Tohoku J Exp Med 201(4):213-219

Kanter M, Coskun O, Korkmaz A, Oter S (2004) Effects of Nigella sativa on oxidative stress and beta-cell damage in streptozotocininduced diabetic rats. Anat Rec Part A Disc Mol Cell Evol Biol 279(1):685-691

Khader M, Bresgen N, Eckl PM (2010) Antimutagenic effects of ethanolic extracts from selected Palestinian medicinal plants. J Ethnopharmacol 127(2):319-324

Khan MA (1999) Chemical composition and medicinal properties of Nigella sativa Linn. Inflammopharmacology 7(1):15-35

Khan MA, Ashfaq MK, Zuberi HS, Mahmood MS, Gilani AH (2003a) The in vivo antifungal activity of the aqueous extract from Nigella sativa seeds. Phytother Res 17(2):183-186
Khan N, Sharma S, Sultana S (2003b) Nigella sativa (black cumin) ameliorates potassium bromate-induced early events of carcinogenesis: diminution of oxidative stress. Human Exp Toxicol 22(4):193-203

Khan MA, Chen HC, Tania M, Zhang DZ (2011) Anticancer activities of Nigella sativa (black cumin). Afr J Tradit Complement Altern Med 8(5 Suppl):226-232

Kirui PK, Cameron J, Benghuzzi HA, Tucci M, Patel R, Adah F et al (2004) Effects of sustained delivery of thymoqiunone on bone healing of male rats. Biomed Sci Instrum 40:111-116

Korany NS, Ezzat BA (2011) Prophylactic effect of green tea and Nigella sativa extracts against fenitrothion-induced toxicity in rat parotid gland. Arch Oral Biol 56(11):1339-1346

Kumara SS, Huat BT (2001) Extraction, isolation and characterisation of antitumor principle, alpha-hederin, from the seeds of Nigella sativa. Planta Med 67(1):29-32

Lahm GP, Cordova D, Barry JD (2009) New and selective ryanodine receptor activators for insect control. Bioorg Med Chem 17:4127-4133

Le PM, Benhaddou-Andaloussi A, Elimadi A, Settaf A, Cherrah Y, Haddad PS (2004) The petroleum ether extract of Nigella sativa exerts lipid-lowering and insulin-sensitizing actions in the rat. J Ethnopharmacol 94(2-3):251-259

Lei X, Lv X, Liu M, Yang Z, Ji M, Guo X et al (2012) Thymoquinone inhibits growth and augments 5-fluorouracil-induced apoptosis in gastric cancer cells both in vitro and in vivo. Biochem Biophys Res Commun 417(2):864-868

Mabrouk GM, Moselhy SS, Zohny SF, Ali EM, Helal TE, Amin AA et al (2002) Inhibition of methylnitrosourea (MNU) induced oxidative stress and carcinogenesis by orally administered bee honey and Nigella grains in Sprague Dawely rats. J Exp Clin Cancer Res 21(3):341-346

Mahmood MS, Gilani AH, Khwaja A, Rashid A, Ashfaq MK (2003) The in vitro effect of aqueous extract of Nigella sativa seeds on nitric oxide production. Phytother Res 17(8):921-924

Mahmoud MR, El-Abhar HS, Saleh S (2002) The effect of Nigella sativa oil against the liver damage induced by Schistosoma mansoni infection in mice. J Ethnopharmacol 79(1):1-11

Majdalawieh AF, Hmaidan R, Carr RI (2010) Nigella sativa modulates splenocyte proliferation, Th1/Th2 cytokine profile, macrophage function and NK anti-tumor activity. J Ethnopharmacol 131(2):268-275

Mansour M, Tornhamre S (2004) Inhibition of 5-lipoxygenase and leukotriene $\mathrm{C} 4$ synthase in human blood cells by thymoquinone. J Enzyme Inhib Med Chem 19(5):431-436

Mansour MA, Ginawi OT, El-Hadiyah T, El-Khatib AS, Al-Shabanah OA, Al-Sawaf HA (2001) Effects of volatile oil constituents of Nigella sativa on carbon tetrachloride-induced hepatotoxicity in mice: evidence for antioxidant effects of thymoquinone. Res Commun Mol Pathol Pharmacol 110(3-4):239-251

Mansour SW, Sangi S, Harsha S, Khaleel MA, Ibrahim AR (2013) Sensibility of male rats fertility against olive oil, Nigella sativa oil and pomegranate extract. Asian Pac J Trop Biomed $\mathrm{B}(7): 563-568$

Maxwell BD (2000) The radiolabeled syntheses of JV 485, a herbicide candidate for winter wheat. J Labelled Comp Radiopharm 43:645-654

Meral I, Kanter M (2003) Effects of Nigella sativa L. and Urtica dioica $\mathrm{L}$. on selected mineral status and hematological values in CCl4-treated rats. Biol Trace Elem Res 96(1-3):263-270

Meral I, Yener Z, Kahraman T, Mert N (2001) Effect of Nigella sativa on glucose concentration, lipid peroxidation, anti-oxidant defence system and liver damage in experimentally-induced diabetic rabbits. J Vet Med A Physiol Pathol Clin Med 48(10):593-599

Michelitsch A, Rittmannsberger A, Hufner A, Ruckert U, Likussar W (2004) Determination of isopropylmethylphenols in black seed 
oil by differential pulse voltammetry. Phytochem Anal 15(5):320-324

Morikawa T, Xu F, Ninomiya K, Matsuda H, Yoshikawa M (2004a) Nigellamines A3, A4, A5, and C, new dolabellane-type diterpene alkaloids, with lipid metabolism-promoting activities from the Egyptian medicinal food black cumin. Chem Pharm Bull 52(4):494-497

Morikawa T, Xu F, Kashima Y, Matsuda H, Ninomiya K, Yoshikawa M (2004b) Novel dolabellane-type diterpene alkaloids with lipid metabolism promoting activities from the seeds of Nigella sativa. Org Lett 6(6):869-872

Morsi NM (2000) Antimicrobial effect of crude extracts of Nigella sativa on multiple antibiotics-resistant bacteria. Acta Microbiol Pol 49(1):63-74

Nair SC, Salomi MJ, Panikkar B, Panikkar KR (1991) Modulatory effects of Crocus sativus and Nigella sativa extracts on cisplatininduced toxicity in mice. J Ethnopharmacol 31(1):75-83

Nickavar B, Mojab F, Javidnia K, Amoli MA (2003) Chemical composition of the fixed and volatile oils of Nigella sativa $\mathrm{L}$. from Iran. Z Naturforsch C 58(9-10):629-631

Okuno S, Saito A, Hayashi T, Chan PH (2004) The c-Jun N-terminal protein kinase signaling pathway mediates Bax activation and subsequent neuronal apoptosis through interaction with Bim after transient focal cerebral ischemia. J Neurosci 24(36):7879-7887

Paarakh PM (2010) Nigella sativa Linn-a comprehensive review. Indian. J Nat Prod Res 1(4):409-429

Penning TD, Talley JJ, Bertenshaw SR, Carter JS, Collins WP, Docter $S$ et al (1997) Synthesis and Biological evaluation of the 1,5diarylpyrazole class of cyclooxygenase- 2 inhibitors: identification of 4-[5-(4-methylphenyl)-3-(trifluoromethyl)-1H-pyrazol-1yl]benzenesulfonamide (SC-58635, Celecoxib). J Med Chem 40:1347-1365

Plosker GL, Goa KL (1991) Granisetron. A review of its pharmacological properties and therapeutic use as an antiemetic. Drugs 42(5):805-824

Rastogi L, Feroz S, Pandey BN, Jagtap A, Mishra KP (2010) Protection against radiation-induced oxidative damage by an ethanolic extract of Nigella sativa L. Int $\mathrm{J}$ Rad Biol 86(9):719-731

Ravindran J, Nair HB, Sung B, Prasad S, Tekmal RR, Aggarwal BB (2010) Thymoquinone poly (lactide-co-glycolide) nanoparticles exhibit enhanced anti-proliferative, anti-inflammatory, and chemosensitization potential. Biochem Pharmacol 79(11):1640-1647

Rchid H, Chevassus H, Nmila R, Guiral C, Petit P, Chokairi M et al (2004) Nigella sativa seed extracts enhance glucose-induced insulin release from rat-isolated Langerhans islets. Fundam Clin Pharmacol 18(5):525-529

Saleem U, Ahmad B, Rehman K, Mahmood S, Alam M, Erum A (2012) Nephro-protective effect of vitamin C and Nigella sativa oil on gentamicin associated nephrotoxicity in rabbits. Pak $\mathrm{J}$ Pharm Sci 25(4):727-730

Salim EI, Fukushima S (2003) Chemopreventive potential of volatile oil from black cumin (Nigella sativa L.) seeds against rat colon carcinogenesis. Nutr Cancer 45(2):195-202
Salomi MJ, Nair SC, Panikkar KR (1991) Inhibitory effects of Nigella sativa and saffron (Crocus sativus) on chemical carcinogenesis in mice. Nutr Cancer 16(1):67-72

Salomi NJ, Nair SC, Jayawardhanan KK, Varghese CD, Panikkar KR (1992) Antitumour principles from Nigella sativa seeds. Cancer Lett 63(1):41-46

Samarakoon SR, Thabrew I, Galhena PB, De Silva D, Tennekoon KH (2010) A comparison of the cytotoxic potential of standardized aqueous and ethanolic extracts of a polyherbal mixture comprised of Nigella sativa (seeds), Hemidesmus indicus (roots) and Smilax glabra (rhizome). Pharmacognosy Res 2(6):335-342

Samarakoon SR, Thabrew I, Galhena PB, Tennekoon KH (2012) Modulation of apoptosis in human hepatocellular carcinoma (HepG2 cells) by a standardized herbal decoction of Nigella sativa seeds, Hemidesmus indicus roots and Smilax glabra rhizomes with anti-hepatocarcinogenic effects. BMC Complement Altern Med 12:25. doi:10.1186/1472-6882-12-25

Shafi G, Munshi A, Hasan TN, Alshatwi AA, Jyothy A, Lei DK (2009) Induction of apoptosis in HeLa cells by chloroform fraction of seed extracts of Nigella sativa. Cancer Cell Int 9:29. doi:10.1186/1475-2867-9-29

Singh A, Ahmad I, Akhter S, Jain GK, Iqbal Z, Talegaonkar S, Ahmad FJ (2013) Nanocarrier based formulation of thymoquinone improves oral delivery: stability assessment, in vitro and in vivo studies. Colloids Surf B 102:822-832

Steinmann A, Schatzle M, Agathos M, Breit R (1997) Allergic contact dermatitis from black cumin (Nigella sativa) oil after topical use. Contact Dermatitis 36(5):268-269

Swamy SM, Huat BT (2003) Intracellular glutathione depletion and reactive oxygen species generation are important in alphahederin-induced apoptosis of P388 cells. Mol Cell Biochem 245(1-2):127-139

Swamy SM, Tan BK (2000) Cytotoxic and immunopotentiating effects of ethanolic extract of Nigella sativa L. seeds. J Ethnopharmacol 70(1):1-7

Ulu R, Dogukan A, Tuzcu M, Gencoglu H, Ulas M, Ilhan N et al (2012) Regulation of renal organic anion and cation transporters by thymoquinone in cisplatin induced kidney injury. Food Chem Toxicol 50(5):1675-1679

Verma SK, Rastogi S, Javed K, Akhtar M, Arorac I, Samim M (2013) Nanothymoquinone, a novel hepatotargeted delivery system for treating $\mathrm{CCl} 4$ mediated hepatotoxicity in rats. J Mater Chem B 1:2956-2966

Worthen DR, Ghosheh OA, Crooks PA (1998) The in vitro anti-tumor activity of some crude and purified components of blackseed Nigella sativa L. Anticancer Res 18(3A):1527-1532

Ye M, Edmunds AJF, Morris JA, Sale D, Zhanga Y, Yu J-Q (2013) A robust protocol for $\mathrm{Pd}(\mathrm{II})$-catalyzed $\mathrm{C}-3$ arylation of $(1 \mathrm{H})$ indazoles and pyrazoles: total synthesis of nigellidine hydrobromide. Chem Sci 4:2374-2379

Yusufi M, Banerjee S, Mohammad M, Khatal S, Swamy KV, Khan EM et al (2013) Synthesis, characterization and anti-tumor activity of novel thymoquinone analogs against pancreatic cancer. Bioorg Med Chem Lett 23:3101-3104 